\title{
М.Г. Семчишин
}

\section{ЗМІНИ ВМІСТУ МІКРОЕЛЕМЕНТІВ СЕЛЕНУ І КОБАЛЬТУ В СИРОВАТЦІ КРОВІ ХВОРИХ ПРИ ЧЕРЕПНО - МОЗКОВІЙ ТРАВМІ В ГОСТРОМУ ТА ПРОМІЖНОМУ ПЕРІОДАХ}

Державний заклад клінічна лікарня "Державно-територіальне галузеве об'єднання" Львівської залізниці

Резюме. У статті наведені дані про зміни вмісту мікроелементів селену і кобальту при черепно - мозковій травмі (ЧМТ) легкого і середнього ступенів тяжкості в гострому та проміжному періодах. Досліджувались їх концентрації в сироватці крові хворих атомно - абсорбційним методом на 1-2, 3-5, 7-10, 14-21-шу добу, через один і три місяці після травми. Встановлено, що вміст кобальту в сироватці крові хворих при ЧМТ різного ступеня тяжкості практично не змінюється $(\mathrm{p}>0,05)$ порівняно 3 контролем упродовж всього періоду спостереження. Також не відмічається істотних змін даного мікроелемента в сироватці крові між досліджуваними групами подобово $(\mathrm{p}>0,05)$. При дослідженні вмісту селену в сироватці крові хворих при ЧМТ вста-

Вступ. Мікроелементи відіграють важливу роль у регуляції процесів життєдіяльності та беруть участь у багатьох біохімічних реакціях, що відбуваються в організмі людини $[1,2,12]$. Регуляторна роль мікроелементів може бути порівняна $з$ регуляторною значимістю гормонів [9]. Недостатність або надлишок мікроелементів призводить до патологічних станів, головним чином, за рахунок змін синтезу ферментів, до складу яких вони входять. Мікроелементи виконують роль кофакторів майже 300 ферментів $[1,2,9]$.

Селен (Se) активує холінестеразу й глутатіонпероксидазу, що захищає клітини від накопичення продуктів перекисного окиснення, тим самим запобігаючи руйнування їх ядерного та білок-синтезуючого апарату, отже, регулює вільнорадикальне окиснення, яке супроводжується змінами в обміні ліпідів, пригніченням гліколізу, синтезу глікогену $[3,4,9]$. Селен є синергістом вітаміну Е, сприяє підвищенню його антиоксидантної активності та входить до складу ферменту, що контролює утворення трийодтироніну [15, 17]. Доведений зв'язок окиснювально-відновних процесів і апоптозу та необхідність взаємодії селену із цинк-вмісними білками для процесів репарації ДНК. Порушення цієї взаємодії призводить до канцерогенезу і мутагенезу. Важливу роль селен відіграє у функціонуванні імунної системи, а також в антагонізмі з важкими металами $[16,18]$. Показано протекторну роль селену при накопиченні в організмі кадмію, ртуті та ванадію [2, 10, 13].

Кобальт (Со) відноситься до есенційних мікроелементів, а його біологічна функція пов'язана 3 наявністю в молекулі вітаміну $\mathrm{B}_{12}$, тому на думку авторів, його дефіцит є недостатністю вітаміну $\mathrm{B}_{12}$ [10]. Всмоктування кобальту і заліза підвищується при дефіциті останнього, що вказує на спільність механізму всмоктування обох мікроелементів [8].

(C) М.Г. Семчишин, 2015 новлено, що його концентрація практично не відрізнялася від контролю в групі осіб із струсом та забоєм головного мозку легкого ступеня $(\mathrm{p}>0,05)$ та неістотно знижувалась у групі осіб із забоєм головного мозку середнього ступеня тяжкості $(\mathrm{p}>0,05)$ упродовж всього періоду спостереження. Однак не зважаючи на те, що рівень селену в сироватці крові хворих при ЧМТ протягом періоду спостереження достовірно не змінюється щодо контролю, наявні достовірні зміни його вмісту в сироватці крові осіб між досліджуваними групами $\left(\mathrm{p}_{1}<0,05 ; \mathrm{p}_{2}<0,05 ; \mathrm{p}_{3}<0,05\right)$.

Ключові слова: селен, кобальт, черепно - мозкова травма, гострий та проміжний періоди.

Виведення кобальту відбувається із сечею, існує прямий зв'язок між дозою і вмістом його в сечі [1, $9,10]$. Концентрація кобальту є значно вищою в еритроцитах, аніж у плазмі. У сироватці крові кобальт зв'язується з альбуміновою фракцією $[8,10]$. У фізіологічних концентраціях кобальт необхідний організму для нормальної життєдіяльності, а його дефіцит викликає зниження пам'яті, загальмованість, маразм, натомість надлишок - міокардіодистрофію, гіперплазію щитоподібної залози, алергодерматит, пневмосклероз [8, 9]. Показано, що кобальт активує перекисне окиснення ліпідів і розвиток оксидантного стресу, пригнічує синтез ДНК в лімфоцитах, викликає активацію ксантиноксидази, інгібує синтазу оксиду азоту, а надлишок його призводить до апоптозу і алергічних реакцій. Встановлено, що даний мікроелемент у надлишковій концентрації має також ферментну і цитотоксичну дію, впливаючи на мітохондрії клітин $[1,2$, 9, 10, 12].

Дослідження патогенезу ЧМТ є актульним питанням сьогодення [7,13, 14]. Велика увага відводиться пошуку біохімічних маркерів, що пов'язане із неможливістю пояснити розвиток всіх патологічних проявів ураження мозку виключно за рахунок його механічних пошкоджень $[5,6,13]$. Дослідження мінерального гомеостазу може стати одним із таких напрямків. При спектральному аналізі сироватки крові можна виявляти дефіцит або надлишок елементів в організмі, що використовується в багатьох галузях медицини і є основою для розробки нових лікувальних технологій шляхом корекції мікроелементозів.

Мета дослідження. Дослідити вміст селену і кобальту в сироватці крові хворих при ЧМТ легкого і середнього ступенів тяжкості в гострому i проміжному періодах.

Матеріал і методи. Обстежено 283 пацієнти із ЧМТ легкого і середнього ступенів тяжкості в 
гострому і проміжному періодах, які перебували на стаціонарному лікуванні в державному закладі клінічної лікарні "державно-територіального галузевого об'єднання" Львівської залізниці. Кров для спектрального аналізу забирали в пацієнтів із вени натще на 1-2, 3-5, 7-10, 14-21-шу доби, через один і три місяці після травми. Пацієнти були розподілені на три групи: 1-ша - струс головного мозку (СГМ) - 143 особи (50,53\%); 2-га - забій головного мозку легкого ступеня тяжкості (ЗГМЛС) - 119 осіб (42,05 \%); 3-тя - забій головного мозку середнього ступеня тяжкості (ЗГМСС) - 21 особа (7,42 \%). Вік пацієнтів 20-55 років. Контрольну групу склали 20 практично здорових осіб віком 18-50 років. Концентрацію селену і кобальту в сироватці крові хворих визначали за допомогою методу атомної абсорбції. Результати оброблені статистичними методами [11]. Достовірними вважали величини $\mathrm{p}<0,05$.

Результати дослідження та їх обговорення. Результати проведеного дослідження вмісту селену та кобальту в сироватці крові хворих подано в таблицях 1 і 2.

Як видно із табл. 1, у пацієнтів із СГМ і ЗГМЛС рівень селену протягом всього періоду спостереження не відрізнявся від групи контролю ( $>>0,05)$, однак у групі осіб із ЗГМСС ми відмічали зниження вмісту даного мікроелемента в гострому і проміжному періодах відносно контролю, хоча ці показники були недостовірними ( $>00,05)$.

При порівнянні даних дослідження в динаміці встановлені достовірні зміни вмісту селену в сироватці крові осіб між досліджуваними групами $\left(\mathrm{p}_{1}<0,05 ; \mathrm{p}_{2}<0,05 ; \mathrm{p}_{3}<0,05\right)$. Так, у групі пацієнтів із СГМ через три місяці після травми рівень селену збільшується, що вказує, очевидно, на зниження інтенсивності процесів перекисного окиснення ліпідів і синдрому ендогенної інтоксикації. Однак у групі осіб із ЗГМЛС його концентрація істотно зменшується, що підтверджує гіпотезу наростання явищ запалення і апоптозу та вираження синдрому ендогенної інтоксикації при завершенні гострого і проміжного періодів ЧМТ. Наші дані збігаються з результатами досліджень кафедри неврології і нейрохірургії факультету післядипломної освіти Львівського національного медичного університету імені Данила Галицького, які довели, що за ступенем вираженості синдрому ендогенної інтоксикації можна судити про тяжкість травматичного процесу і прогнозувати його перебіг $[4,5]$.

Таким чином, отримані дані засвідчують роль селену в механізмі антиоксидантного захисту. Рівень його в сироватці крові корелює зі ступенем тяжкості перенесеної ЧМТ, що призводить до розвитку ураження нейронів головного мозку.

Як видно із табл. 2, вміст кобальту в сироватці крові осіб при ЧМТ різного ступеня тяжкості істотно не змінюється $(\mathrm{p}>0,05)$ порівняно 3 контролем протягом всього періоду спостереження. Також не відмічається достовірних змін його концентрації в сироватці крові пацієнтів залежно від періоду спостереження (від 1-2-ї доби до трьох місяців, $\mathrm{p}>0,05)$ і між досліджуваними групами $\left(\mathrm{p}_{1}>0,05 ; \mathrm{p}_{2}>0,05 ; \mathrm{p}_{3}>0,05\right)$.

Отже, вивчаючи вміст селену і кобальту в сироватці крові пацієнтів при ЧМТ у гострому i проміжному періодах, можемо стверджувати, що ïx показники будуть корисними як один із критеріїв визначення тяжкості травматичного процесу і доповнюватимуть базисну схему терапії.

Таблиця 1

Концентрація селену в сироватці крові хворих при ЧМТ легкого і середнього ступенів тяжкості в гострому і проміжному періодах і в осіб контрольної групи (мкмоль/л)

\begin{tabular}{|c|c|c|c|c|c|c|}
\hline \multirow[b]{2}{*}{$\begin{array}{c}\text { Групи хво- } \\
\text { рих }\end{array}$} & \multicolumn{6}{|c|}{ Подобове дослідження селену, мкмоль/л } \\
\hline & $\begin{array}{c}\text { 1-2-га доба } \\
\mathrm{M} \pm \mathrm{m}\end{array}$ & $\begin{array}{c}\text { 3-5-та доба } \\
\mathrm{M} \pm \mathrm{m}\end{array}$ & $\begin{array}{c}\text { 7-10-та доба } \\
\mathrm{M} \pm \mathrm{m}\end{array}$ & $\begin{array}{c}\text { 14-21-ша } \\
\text { доба } \\
\mathrm{M} \pm \mathrm{m}\end{array}$ & $\begin{array}{c}\text { через } 1 \text { міс. } \\
\text { M } \pm \mathrm{m}\end{array}$ & $\begin{array}{c}\text { через } 3 \text { міс. } \\
\qquad \pm m\end{array}$ \\
\hline $\begin{array}{c}\text { СГМ } \\
(\mathrm{n}=143)\end{array}$ & $\begin{array}{c}2,018 \pm 0,002 \\
\mathrm{p}>0,05 \\
\mathrm{p}_{1}<0,05\end{array}$ & $\begin{array}{c}2,016 \pm 0,001 \\
\mathrm{p}>0,05 \\
\mathrm{p}_{1}<0,05\end{array}$ & $\begin{array}{c}2,012 \pm 0,004 \\
\mathrm{p}>0,05 \\
\mathrm{p}_{1}<0,05\end{array}$ & $\begin{array}{c}2,012 \pm 0,004 \\
\mathrm{p}>0,05 \\
\mathrm{p}_{1}<0,05\end{array}$ & $\begin{array}{c}2,018 \pm 0,002 \\
\mathrm{p}>0,05 \\
\mathrm{p}_{1}<0,05\end{array}$ & $\begin{array}{c}2,043 \pm 0,004 \\
\mathrm{p}>0,05 \\
\mathrm{p}_{1}<0,05\end{array}$ \\
\hline $\begin{array}{l}\text { ЗГМЛС } \\
(\mathrm{n}=119)\end{array}$ & $\begin{array}{c}2,080 \pm 0,004 \\
\mathrm{p}>0,05 \\
\mathrm{p}_{2}<0,05\end{array}$ & $\begin{array}{c}2,081 \pm 0,003 \\
\mathrm{p}>0,05 \\
\mathrm{p}_{2}<0,05\end{array}$ & $\begin{array}{c}2,081 \pm 0,003 \\
\mathrm{p}>0,05 \\
\mathrm{p}_{2}<0,05\end{array}$ & $\begin{array}{c}2,083 \pm 0,003 \\
\mathrm{p}>0,05 \\
\mathrm{p}_{2}<0,05\end{array}$ & $\begin{array}{c}2,083 \pm 0,003 \\
\mathrm{p}>0,05 \\
\mathrm{p}_{2}<0,05\end{array}$ & $\begin{array}{c}2,062 \pm 0,003 \\
\mathrm{p}>0,05 \\
\mathrm{p}_{2}<0,05\end{array}$ \\
\hline $\begin{array}{c}\text { ЗГМСС } \\
(\mathrm{n}=21)\end{array}$ & $\begin{array}{c}1,973 \pm 0,005 \\
\mathrm{p}>0,05 \\
\mathrm{p}_{3}<0,05\end{array}$ & $\begin{array}{c}1,965 \pm 0,001 \\
\mathrm{p}>0,05 \\
\mathrm{p}_{3}<0,05\end{array}$ & $\begin{array}{c}1,962 \pm 0,008 \\
\mathrm{p}>0,05 \\
\mathrm{p}_{3}<0,05\end{array}$ & $\begin{array}{c}1,961 \pm 0,008 \\
\mathrm{p}>0,05 \\
\mathrm{p}_{3}<0,05\end{array}$ & $\begin{array}{c}1,963 \pm 0,008 \\
\mathrm{p}>0,05 \\
\mathrm{p}_{3}<0,05\end{array}$ & $\begin{array}{c}1,963 \pm 0,008 \\
\mathrm{p}>0,05 \\
\mathrm{p}_{3}<0,05\end{array}$ \\
\hline $\begin{array}{c}\text { Контрольна } \\
\text { група } \\
(\mathrm{n}=20)\end{array}$ & \multicolumn{6}{|c|}{$2,077 \pm 0,057$} \\
\hline
\end{tabular}

Примітка. $\mathrm{p}>0,05$ по відношенню рівня контролю; $\mathrm{p}_{1}<0,05$ у пацієнтів із СГМ по відношенню до $3 Г М Л С ; ~ p_{2}<0,05$ у пацієнтів із СГМ по відношенню до ЗГМСС; $\mathrm{p}_{3}<0,05$ у пацієнтів із ЗГМЛС по відношенню до ЗГМСС 
Таблиця 2

Концентрація кобальту в сироватці крові хворих при ЧМТ легкого і середнього ступенів тяжкості в гострому і проміжному періодах і в осіб групи контролю (мкмоль/л)

\begin{tabular}{|c|c|c|c|c|c|c|}
\hline \multirow[b]{2}{*}{$\begin{array}{c}\text { Групи хво- } \\
\text { рих }\end{array}$} & \multicolumn{6}{|c|}{ Подобове дослідження кобальту, мкмоль/л } \\
\hline & $\begin{array}{c}\text { 1-2-га доба } \\
\mathrm{M} \pm \mathrm{m}\end{array}$ & $\begin{array}{c}\text { 3-5-та доба } \\
\text { M } \pm m\end{array}$ & $\begin{array}{c}\text { 7-10-та доба } \\
\mathrm{M} \pm \mathrm{m}\end{array}$ & $\begin{array}{c}\text { 14-21-ша } \\
\text { доба } \\
\mathrm{M} \pm \mathrm{m} \\
\end{array}$ & $\begin{array}{c}\text { через } 1 \text { міс. } \\
\mathrm{M} \pm \mathrm{m}\end{array}$ & $\begin{array}{c}\text { через } 3 \text { міс. } \\
\mathrm{M} \pm \mathrm{m}\end{array}$ \\
\hline $\begin{array}{c}\text { СГМ } \\
(\mathrm{n}=143)\end{array}$ & $\begin{array}{c}0,386 \pm 0,002 \\
\mathrm{p}>0,05 \\
\mathrm{p}_{1}>0,05\end{array}$ & $\begin{array}{c}0,388 \pm 0,002 \\
\mathrm{p}>0,05 \\
\mathrm{p}_{1}>0,05\end{array}$ & $\begin{array}{c}0,388 \pm 0,002 \\
\mathrm{p}>0,05 \\
\mathrm{p}_{1}>0,05\end{array}$ & $\begin{array}{c}0,387 \pm 0,002 \\
\mathrm{p}>0,05 \\
\mathrm{p}_{1}>0,05\end{array}$ & $\begin{array}{c}0,386 \pm 0,002 \\
\mathrm{p}>0,05 \\
\mathrm{p}_{1}>0,05\end{array}$ & $\begin{array}{c}0,386 \pm 0,002 \\
\mathrm{p}>0,05 \\
\mathrm{p}_{1}>0,05\end{array}$ \\
\hline $\begin{array}{l}\text { ЗГМЛС } \\
(\mathrm{n}=119)\end{array}$ & $\begin{array}{l}0,388 \pm \\
0,0003 \\
\mathrm{p}>0,05 \\
\mathrm{p}_{2}>0,05\end{array}$ & $\begin{array}{l}0,390 \pm \\
0,0001 \\
\mathrm{p}>0,05 \\
\mathrm{p}_{2}>0,05\end{array}$ & $\begin{array}{l}0,390 \pm \\
0,0001 \\
p>0,05 \\
p_{2}>0,05\end{array}$ & $\begin{array}{l}0,389 \pm \\
0,0001 \\
\mathrm{p}>0,05 \\
\mathrm{p}_{2}>0,05\end{array}$ & $\begin{array}{l}0,388 \pm \\
0,0003 \\
\mathrm{p}>0,05 \\
\mathrm{p}_{2}>0,05\end{array}$ & $\begin{array}{l}0,388 \pm \\
0,0003 \\
\mathrm{p}>0,05 \\
\mathrm{p}_{2}>0,05\end{array}$ \\
\hline $\begin{array}{c}\text { ЗГМСС } \\
(\mathrm{n}=21)\end{array}$ & $\begin{array}{c}0,390 \pm 0,004 \\
\mathrm{p}>0,05 \\
\mathrm{p}_{3}>0,05\end{array}$ & $\begin{array}{c}0,390 \pm 0,004 \\
\mathrm{p}>0,05 \\
\mathrm{p}_{3}>0,05\end{array}$ & $\begin{array}{c}0,391 \pm 0,004 \\
\mathrm{p}>0,05 \\
\mathrm{p}_{3}>0,05\end{array}$ & $\begin{array}{c}0,391 \pm 0,004 \\
\mathrm{p}>0,05 \\
\mathrm{p}_{3}>0,05\end{array}$ & $\begin{array}{c}0,390 \pm 0,004 \\
\mathrm{p}>0,05 \\
\mathrm{p}_{3}>0,05\end{array}$ & $\begin{array}{c}0,390 \pm 0,004 \\
\mathrm{p}>0,05 \\
\mathrm{p}_{3}>0,05\end{array}$ \\
\hline $\begin{array}{c}\text { Контрольна } \\
\text { група } \\
(\mathrm{n}=20) \\
\end{array}$ & \multicolumn{6}{|c|}{$0,411 \pm 0,035$} \\
\hline
\end{tabular}

Примітка. $\mathrm{p}>0,05$ по відношенню рівня контролю; $\mathrm{p}_{1}>0,05$ у пацієнтів із СГМ по відношенню до ЗГМЛС; $\mathrm{p}_{2}>0,05$ у пацієнтів із СГМ по відношенню до ЗГМСС; $\mathrm{p}_{3}>0,05$ у пацієнтів із ЗГМЛС по відношенню до ЗГМСС

\section{Висновки}

1. У сироватці крові осіб із черепномозковою травмою в гострому і проміжному періодах вірогідних змін вмісту кобальту порівняно 3 показниками контролю та між досліджуваними групами упродовж всього періоду спостереження нами не виявлено ( $>00,05)$.

2. Концентрація селену в сироватці крові при черепно-мозковій травмі практично не відрізнялася від даних контрольної групи в групах осіб із струсом головного мозку і забоєм головного мозку легкого ступеня тяжкості та недостовірно знижувалась у групі пацієнтів із забоєм головного мозку середнього ступеня тяжкості упродовж всього періоду спостереження ( $>>0,05)$.

3. При порівнянні рівня селену в сироватці крові осіб із черепно-мозковою травмою в гострому і проміжному періодах між досліджуваними групами встановлені достовірні відмінності $\left(\mathrm{p}_{1}<0,05 ; \mathrm{p}_{2}<0,05 ; \mathrm{p}_{3}<0,05\right)$.

Перспективи подальших досліджень. Подальше вивчення вмісту мікроелементів у сироватці крові пацієнтів при ЧМТ у гострому і проміжному періодах допоможе розширити існуючі уявлення про їхню роль у патогенезі травматичного процесу та дасть можливість використовувати їх як допоміжний показник для диференціації визначення ступеня тяжкості ЧМТ. Дані дослідження можуть мати діагностично-прогностичне значення, слугуватимуть в експертних цілях та допоможуть клініцистам у підборі патогенетичної терапії з урахуванням чільних порушень мінерального гомеостазу.

\section{Література}

1. Авцын А.П. Микроэлементозы человека / Авцын А.П., Жаворонков А.Л., Строчкова Л.С. - М.: Медицина, 1991. $-496 \mathrm{c}$.
2. Бабенко Г.А. Микроэлементы человека: патогенез, профилактика, лечение / Г.А. Бабенко // Микроэлементы в мед. -2001 . - № 2. - С. 2-5.

3. Білошицький В.В. Ендогенна інтоксикація при черепно-мозковій травмі та ії корекція методом ентеросорбції: автореф. дис. на здобуття наук. ступеня канд. мед. наук: спец. 14.01.05 «Нейрохірургія» / В.В. Білошицький. - К., 1998. - 17 с.

4. Задорожна Б.В. Клініко-параклінічні характеристики гострого i проміжного періодів легкої черепномозкової травми: автореф. дис. на здобуття наук. ступеня канд. мед. наук: спец. 14.01.15 «Нервові хвороби» / Б.В. Задорожна. - К., 2004. - 21 с.

5. Задорожна Б.В. Травматична хвороба головного мозку (віддалений період черепно-мозкової травми): клінікобіохімічні аспекти, профілактика, лікування: дис. На здоб.наук.ступ. доктора мед. наук: 14.01 .15 / Задорожна Божена Володимирівна. - К., 2012. - 314 с

6. Зозуля Ю.А. Свободно-радикальное окисление и антиоксидантная защита при патологии головного мозга / Ю.А. Зозуля, В.А. Барабой, Д.А. Сутковой. - М.: Знание, 2000. - 344 с.

7. Клиническое руководство по черепно-мозговой травме / под ред. А.Н.Коновалова и др. - М.: Антидор, 1998. - T. 1. $-550 \mathrm{c}$.

8. Мартынова С.Н. Метаболические эффекты меди и кобальта (обзор) / С.Н. Мартынова, В.Н. Зовский // Експерим. і клін. мед. - 2010. - № 2. - С. 42-49.

9. Маршалл В.Дж. Клиническая биохимия / В.Дж. Маршал; пер. с англ. - М., СПб.: Бином - Невский диалект, 2002. $-348 \mathrm{c}$.

10. Охрименко С.М. Адаптация ферментов липидного и азотистого обмена у крыс при оксидативном стрессе, вызванном солями кобальта и ртути / С.М. Охрименко, Н.Ю. Гурьева, П.А. Калиман // Вісн. Харк. нац. унту ім. В.Н.Каразіна. Серія: Біологія. - 2005. - Вип. 1-2, № 709. - С. 56-60

11. Петри А. Наглядная статистика в медицине / А. Петри, К. Сэбин; пер. с англ. - М.: Гэотар - мед., 2003. $144 \mathrm{c}$.

12. Скальный А.В. Микроэлементозы человека (диагностика и лечение) /А.В. Скальный. - М., 2001. $70 \mathrm{c}$. 
13. Черепно-мозкова травма: сучасні принципи невідкладної допомоги: [навчальн. метод. посібн.] / Педаченко Є.Г., Шлапак І.П., Гук А.П., Пилипенко М.М. - К.: Варта, 2007. - $312 \mathrm{c}$.

14. Andrew I.R. Maas Moderate and severe traumatic brain injury in adults / Andrew I.R. Maas, Nino Stocchetti, Ross Bullok. // Lancet Neurology. - 2008. - № 7. - P. 728-741.

15. Brown K.M. Selenium, selenoproteins and human health: a review / K.M. Brown, J.R. Arthur // Public Health Nutr. - 2001. - Vol. 4, № 2. - P. 593-602.
16. Gennarelli T.A. The pathobiology of traumatic brain injury / T.A. Gennarelli // Neuroscientist. - 1997. - Vol. 3. - P. 73-81.

17. Selenium and selenoproteins in health and disease / L.V.Papp, A.Holmgren, K.K.Khanna [et al.] // Antioxid. Redox. Signal. - 2010. - Vol. 12. - P. 793-798.

18. Seleniun and the endocrine system / J. Kohrle, F. Jakob, B. Contempre [et al.] // Endocrinology Rev. - 2005. Vol. 26. - P. 944-984.

\section{ИЗМЕНЕНИЯ УРОВНЕЙ МИКРОЭЛЕМЕНТОВ СЕЛЕНА И КОБАЛЬТА В СЫВОРОТКЕ КРОВИ БОЛЬНЫХ ПРИ ЧЕРЕПНО-МОЗГОВОЙ ТРАВМЕ В ОСТРОМ И ПРОМЕЖУТОЧНОМ ПЕРИОДАХ}

\section{М.Г. Семчишин}

Резюме. В статье представлены данные об изменениях содержимого микроэлементов селена и кобальта при черепно-мозговой травме (ЧМТ) легкой и средней степени тяжести в остром и промежуточном периодах. Исследовались их концентрации в сыворотке крови больных атомно-абсорбционным методом на 1-2, 3-5, 7-10, 14-21-ые сутки, через один и три месяца после травмы. Установлено, что содержимое кобальта в сыворотке крови больных при ЧМТ разной степени тяжести практически не изменяется (p>0,05) в сравнении с контролем на протяжении всего периода наблюдения. Также не отмечается существенных изменений данного микроэлемента в сыворотке крови между группами исследования посуточно $(\mathrm{p}>0,05)$. При исследовании содержимого селена в сыворотке крови больных при ЧМТ установлено, что его концентрация практически не отличалась от контроля в группе больных с сотрясением и ушибом головного мозга легкой степени $(\mathrm{p}>0,05)$ и несущественно снижалась в группе больных с ушибом головного мозга средней степени тяжести $(\mathrm{p}>0,05)$ на протяжении всего периода наблюдения. Однако, несмотря на то, что уровень селена в сыворотке крови больных при ЧМТ на протяжении периода наблюдения достоверно не изменяется относительно контроля, имеют место достоверные изменения его содержимого в сыворотке крови больных между группами исследования $\left(\mathrm{p}_{1}<0,05 ; \mathrm{p}_{2}<0,05 ; \mathrm{p}_{3}<0,05\right)$.

Ключевые слова: селен, кобальт, черепно-мозговая травма, острый и промежуточный периоды.

\section{THE CHANGES OF SELENIUM AND COBALT TRACE ELEMENTS LEVEL IN THE BLOOD SERUM OF PATIENTS IN THE BRAIN INJURY DURING ACUTE AND INTERMEDIATE PERIODS}

\section{M.G. Semchyshyn}

The purpose. To study the level of trace elements of selenium and cobalt in the blood serum of patients in the brain mild and moderate injury of mild and during acute and intermediate periods.

Methods and subjects. Complex paraclinical examination of 283 patients with brain injury of mild and moderate severity in acute and intermediate periods has been done. 20 almost healthy volunteers made the control group. The level of trace elements of selenium and cobalt in the serum of blood was investigated by means of atomic - absorption spectroscopy.

Results. The concentration of selenium and cobalt in the serum of blood examination on the $1^{\text {st }}-2^{\text {nd }}, 3^{\text {rd }}-5^{\text {th }}, 7^{\text {th }}-10^{\text {th }}$, $14^{\text {th }}-21^{\text {st }}$ days, after 1 and 3 months after trauma was found out. It was established that contents of cobalt in the serum of blood patients in craniocerebral trauma of different degree remained practically invariable $(\mathrm{p}>0,05)$, as compared to the control group during the whole period of observation. Also there were no essential changes in this trace element in the serum of blood between groups of examination daily $(p>0,05)$. In the study of the content of selenium in the serum of patients with head injury it was found that concentrations did not differ from the control group of people with concussion and brain contusion of mild severity $(p>0,05)$ and slightly decreased in the group of people with a brain contusion of medium severity $(p>0,05)$ throughout the period. Although the level of selenium in the serum of patients with head injury during the observation period did not significantly change compared to the control, there are significant changes in its content in the blood serum of individuals between the study groups $(\mathrm{P} 1<0,05 ; \mathrm{p} 2<0,05 ; \mathrm{P} 3<0,05)$.

Area of results application. Neurology.

Conclusion. In the future study of content the trace elements in the serum of blood patients in brain injury in acute and intermediate periods can extend a notion about their role in pathogenesis of traumatic process and give possibility of using these data as supplementary index for differentiation of determination of the degree of craniocerebral trauma severity. These data have diagnostic and prognostic importance and serve with the purpose of professional findings.

Key words: selenium, cobalt, brain injury, acute and intermediate periods.

State institution the Clinical Hospital "State territorial sectoral association" of Lviv Railway

Рецензент - д. мед. н. І.І. Кричун

Buk. Med. Herald. - 2015. - Vol. 19, № 3 (75). - P. 151-154 